
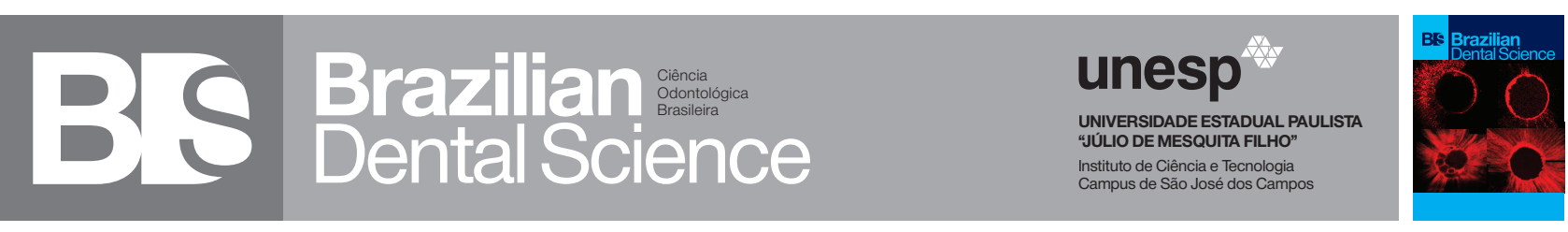

\title{
Influence of root canal filling techniques on sealer penetration and gutta percha/sealer ratio: a confocal laser scanning microscopy analysis
}

Influência das técnicas de obturação do canal radicular na penetração do cimento e na relação guta-percha / cimento: uma análise por microscopia de varredura confocal a laser

Fatma Macit ERMIS ${ }^{1}$, Faruk HAZNEDAROĞLU

1 - Istanbul Medipol University - Department of Endodontics - Faculty of Dentistry - Istanbul - Turkey.

2 - Istanbul University Faculty of Dentistry - Department of Endodontics - Istanbul - Turkey.

\section{ABSTRACT}

Objective: The influence of four root canal filling techniques on the penetration of an endodontic sealer into dentinal tubules and the gutta percha/ sealer ratio (GP/SR) in root canals was evaluated using confocal laser scanning microscopy (CLSM). Material and Methods: Roots of the maxillary central incisors $(n=40)$ were prepared with ProTaper Universal files up to file F5 and assigned to five groups: continuous wave condensation, lateral condensation, single cone, Thermafill ${ }^{\circledR}$, and negative control group. After root canal filling with gutta-percha and AH26, along with the addition of $0.01 \%$ fluorescein, the roots were cut into 2-mm slices. Using CLSM, the specimens were transversely sectioned at 3,6 , and $10 \mathrm{~mm}$ from the apex. Results: Sealer penetration was deeper and more frequent at $10 \mathrm{~mm}$ than at the $6 \mathrm{~mm}$ and $3 \mathrm{~mm}$ for all obturation technique. Penetration was not significantly affected by obturation techniques except single master cone tecnique. Single cone technique demonstrated the lowest sealer penetration at all levels. However, sealer thickness was strongly dependent on obturation technique. Termafill ${ }^{\circledR}$ demostrated superior GP ratio followed by continuous wave condensation, lateral condensation and single cone. Conclusion: In conclusion, the single cone technique resulted in lower sealer penetration than the other techniques, which did not differ significantly from each other. However, sealer thickness was strongly dependent on obturation technique. Termafill ${ }^{\circledR}$ demostrated superior GP ratio followed by continuous wave condensation, lateral condensation and single cone.

\section{KEYWORDS}

Obturation techniques; Dentinal tubule penetration; Gutta percha, sealer ratio; Confocal laser scanning microscopy.

\section{RESUIMO}

Objetivo: A influência de quatro técnicas de obturação do canal radicular na penetração de um cimento endodôntico nos túbulos dentinários e a relação gutapercha / cimento (GP / CIM) em canais radiculares foram avaliadas por microscopia de varredura confocal a laser (MVCL). Material e Métodos: As raízes de incisivos centrais superiores $(n=40)$ foram preparadas com limas ProTaper Universal até a lima F5 e distribuídas em cinco grupos: condensação de onda contínua, condensação lateral, cone único, Thermafill ${ }^{\circledR} \mathrm{e}$ grupo de controle negativo. Após o preenchimento do canal radicular com guta-percha e AH26, juntamente com a adição de $0,01 \%$ de fluoresceína, as raízes foram cortadas em fatias de $2 \mathrm{~mm}$. Usando MVCL, as amostras foram seccionadas transversalmente a 3, 6 e $10 \mathrm{~mm}$ do ápice. Resultados: A penetração do cimento foi mais profunda e mais frequente em $10 \mathrm{~mm}$ do que nos $6 \mathrm{~mm}$ e 3 $\mathrm{mm}$ para todas as técnicas de obturação. A penetração não foi significativamente afetada pelas técnicas de obturação, exceto pela técnica de cone mestre único. A técnica de cone único demonstrou a menor penetração do cimento em todos os níveis. No entanto, a espessura do cimento foi fortemente dependente da técnica de obturação. O Termafill ${ }^{\circledR}$ demonstrou uma relação superior de GP, seguida por condensação de onda contínua, condensação lateral e cone único. Conclusão: Em conclusão, a técnica de cone único resultou em menor penetração do cimento do que as outras técnicas, que nã̃o diferiram significativamente uma da outra. No entanto, a espessura do cimento foi fortemente dependente da técnica de obturação. O Termafill ${ }^{\circledR}$ demonstrou uma relação superior de GP, seguida por condensação contínua das ondas, condensação lateral e cone único.

\section{PALAVRAS-CHAVE}

Técnicas de obturação; Penetração dos túbulos dentinários; Guta-percha, relação de cimento; Microscopia de varredura confocal a laser. 


\section{INTRODUCTION}

$\mathrm{T}$ he success of endodontic treatment depends on the fulfillment of three main principles, also known as the 'endodontic triad'. These principles are debridement, shaping, and three dimensional obturation of the root canal [1,2]. The complex anatomy of root canals makes both shaping and filling difficult [3]. Studies evaluating the success of endodontic treatment have shown that treatment failure is mostly due to insufficent canal filling [4].

A number of different root canal obturation techniques have been developed and many studies have compared their effectiveness [5,6]. Today, the most commonly used root canal obturation materials are gutta-percha (GP) and root canal sealers. Root canal sealers are expected to fill the space between the GP cones, and the space between them and the dentin walls. The most important characteristic of an ideal root obturation sealer is its ability to bind with the dentin walls with good penetration into the dentinal tubules [7]. This ability to penetrate the dentinal tubules is clinically important because it increases the hermetic sealing property of root canal obturation.

Peters [8] and Wu et al. [9] suggest that the purpose of root canal obturation techniques is to increase the volume of GP and decrease the quantity of sealer used between the GP and the canal wall. However, the search for improved and more effective techniques is on. Kontakiotis et al. [10] and DuLac et al. [11] showed that a sealer can shrink during setting and dissolution; this can result in leakage. The most commonly used root canal obturation technique is cold lateral condensation; it is considered to be the gold standard in the industry. Leonardo [12] showed that cold lateral condensation results in the creation of voids, spreader tracts, and scarce surface adaptation to canal walls. Alternatively, plasticized GP techniques have recently been introduced that claim to better seal the root canal. These include continuous wave and Thermafill ${ }^{\circledR}$ obturation techniques that use thermal and/ or frictional heat to plasticize the GP. Dalat and Spangnerg [13] and Schilder [1] showed that this approach led to better adaptation to canal walls, and a greater degree of homogeneity and optimum apical sealing compared to lateral condensation. In addition, the use of GP cones that match the taper and size of rotary nickel-titanium (NiTi) shaping instruments has recently been suggested. Gordon et al. [14] and Romania et al. [15] suggest that GP cones containing larger tapers should be used during the single cone technique following rotary preparation by NiTi shaping instruments.

However, no literature exists claiming whether the single-cone technique provides more or less favorable results in terms of sealer penetration and sealer thickness when compared with lateral condensation, Thermafill ${ }^{\circledR}$ and continuous wave condensation. Therefore, the aim of this study was to evaluate the influence of root canal filling techniques on the penetration of an endodontic sealer into dentinal tubules and the $\mathrm{GP} /$ sealer ratio at different levels in single root canals using confocal laser scanning microscopy (CLSM).

\section{MATERIAL AND METHODS}

\section{Specimen Preparation}

This study was conducted with the approval of the Ethics Committee of Clinical Research of Istanbul University, Istanbul,Turkey (2014/606641). Fifty freshly extracted, single-rooted, human maxillary incisors were used for this study. After extraction, soft tissue remnants were removed using a surgical blade and hard tissue remnants were removed with a scaler. The teeth were then preserved in $0.5 \%$ thymol solution. The experiments were carried out by a single general practise dentist.

For standardization purposes, the dimensions of the teeth were chosen to be between $21 \pm 1 \mathrm{~mm}$ and $25-35 \mathrm{~mm}$ for IAF. The endodontic working lengths were determined visually at $1.00 \mathrm{~mm}$ short of the apical foramen using the No. 10 K-type root files (Maillefer, Ballaigues, Switzerland). ProTaper (Dentsply Maillefer, Ballaigues,Switzerland) with a rotating NiTi system was used for shaping until F5 file. The root canals were irrigated after each file with $2 \mathrm{~mL}$ 
$2.5 \%$ sodium hypochlorite $(\mathrm{NaOCl})$. After shaping of the root canals, $5 \mathrm{ml} \mathrm{17 \%}$ EDTA (CALASEPT) (Endo-Eze ${ }^{\circledR}$, Ultradent, South Jordan, UT, USA) was applied to the canals to wash away the smear layer. EDTA was neutralized by washing with $5 \mathrm{~mL}$ $2.5 \% \mathrm{NaOCl}$, and the root canals were washed with $5 \mathrm{~mL}$ distilled water. Next, the root canals were dried with paper points and randomly allocated to one of four experimental groups according to the filling technique, or a control group as follows: Group 1, continuous wave condensation; Group 2, lateral condensation; Group 3, single master cone; Group 4, Thermafill ${ }^{\circledR}$ (Thermafill $^{\circledR}$, Dentsply Maillefer, Ballaigues, Switzerland); Group 5, negative control group (no filling).

\section{Root Canal Filling}

AH26 (Dentsply, DeTrey/Germany), an epoxy resin-based sealer, was used as a root canal sealer. To obtain confocal microscopy images, AH26 canal sealer was prepared according to manufacturer instructions, and $0.01 \%$ Rhodamine B (Bereket Chemistry Co Ltd., Turkey) was added sparingly. The maximum absorption by the dye is at $565 \mathrm{~nm}$ and the maximum emission at $605 \mathrm{~nm}$. The Rhodamine B dye-sealer mixture was placed in the root canals with a K-file size 50 placed at the working length (WL) in counter-clockwise motion.

Group 1 samples were subjected to continuous wave obturation as described by Buchanan16). In brief, the technique involved the use of System B Heat Source (BeeFill 2 in 1; VDW, Münih, Germany). The experiment was carried out in two steps. First, an F5-size GP cone was placed in the apical third of the root canal. The cone was adjusted with a scalpel at $1 \mathrm{~mm}$ short of working length until tug-back was achieved. Next, a 40/.03 plugger was marked at its binding point within $4 \mathrm{~mm}$ of working length using a rubber stopper. Then, the apical part of the master cone was coated with a thin film of sealer and placed into the canal following coating of the root canal walls with the sealer. Temperature was set to $200^{\circ} \mathrm{C}$ and the touch mode was activated. Next, the heated plugger was driven through the GP at approximately 3-4 mm from the reference point. During the down pack, the plugger was slowly moved apically. Then, the plugger was deactivated and a firm apical pressure was applied for $10 \mathrm{~s}$ followed by a down packing procedure. The remainder of the root canal was filled with the BeeFill 2 in 1 backfill device. Finally, the temperature was set at $160{ }^{\circ} \mathrm{C}$, the plugger was advanced to the apical plug, and heated GP was injected into the canal. During this procedure, as the canal filled, the injector was retracted. The canal was completely filled and condensed using the GP plugger.

Group 2 was obturated by lateral condensation of GP. The apical section of a size 50 GP cone was coated with a thin film of sealer and placed into the canal at full working length. A suitable spreader (Dentsply Maillefer) that reached 1-2 $\mathrm{mm}$ short of the working length was selected for lateral compaction. Accessory cones coated with the sealer were placed in the voids created by the spreader. This was repeated until the spreader could not penetrate more than 1-2 $\mathrm{mm}$ into the canal orifice.

For Group 3, F5 as a single master cone (Dentsply Maillefer) was coated with AH26 sealer and inserted into the root canal. Next, excess GP and sealer were removed with a heated tool until the cement-enamel junction was reached.

For Group 4, the Thermafill System was used. A Thermafill cone of size F5 was preheated using ThermaPrep ${ }^{\circledR}$ Plus (Tulsa Dental, Tulsa, Oklahoma) and carefully placed at the working length.

Group 5 was the negative control group, which was not subjected to root canal filling.

\section{Acquisition \\ Sample Preparation for CLSM and Image}

All samples were kept in an incubator at $37^{\circ} \mathrm{C}$ and $100 \%$ relative humidity for 7 days. The prepared samples were cut into $1-\mathrm{mm}$ discs at levels of 3,6, and $10 \mathrm{~mm}$ from the root apex using an IsoMet device (IsoMet, Buehler, IL, USA) under water cooling. Samples were mounted on a glass slide with a transparent double-sided tape.

Part A: Measurements of GP /Sealer ratio Images acquired by CLSM were transferred 
to a computer and then combined using Adobe Photoshop 6.0 software. Image $\mathrm{J}$ software was used to measure root canal and GP areas in pixel units. These two data were chosen as the root sealer area for that level. Next, the rate and percentage of the GP-covered area was calculated by dividing the GP-covered area by the total canal area to calculate the Gutta-Percha/Sealer Ratio (GP/SR). During these calculations, the plastic core area using thermoplastic methods was also evaluated as the GP area.

\section{Part B: Depth of Sealer Penetration}

A measurement scale LAS-AF microscopic software (Leica, Buffalo Grove, IL, USA) was used to measure the maximum depth of sealer penetration at four different points in each section. Maximum depth of tubule penetration by the sealer was calculated as follows: the canal wall served as the starting point and the deepest sealer penetration into dentinal tubules was measured to calculate maximum depth of penetration. An Exce ${ }^{\circledR}$ spreadsheet was used to average these data points to obtain a single measure for each section.

\section{Statistical analysis}

SPSS statistics 22 software package (IBM SPSS, Turkey) was used for all statistical analyses. For normally distributed parameters, a One-Way ANOVA test and a Tamhane's T2 test vs Tukey's HSD test were used for within-group comparisons. Variance analysis and the Bonferroni method were used for between-group comparisons. The Friedman test and the Bonferroni-corrected Wilcoxon-signed rank test were used for withingroup comparisons, and the Kruskal-Wallis and Bonferroni-corrected Mann-Whitney $U$ tests for between-group comparisons for parameters without a normal distribution. $\mathrm{P}<0.05$ was considered statistically significant.

\section{RESULTS}

The mean ( \pm standard deviations) of sealer penetration depths are presented in Table 1 . There was no significant difference in the results between the three sections (coronal, middle, and apical) in any of the groups, except for Group 4, where Thermafill ${ }^{\circledR}$ was used. In this group, coronal thirds had the highest values and apical thirds the lowest; the difference between these two values was statistically significant $(\mathrm{P}<0.05)$. However, there was no statistically significant difference between the coronal and middle sections in this group ( $\mathrm{P}>0.05)$.

At a level of $3 \mathrm{~mm}$, there was no significant difference in the depth of sealer penetration between Thermafill ${ }^{\circledR}$, lateral condensation, and continuous wave condensation $(\mathrm{P}>0.05)$, whereas single cone showed the least penetration $(P<0.05)$. At a level of $6 \mathrm{~mm}$, Thermafill ${ }^{\circledR}$ and lateral condensation showed the best outcomes (P $>0.05$ ); however, single cone, similar to the $3 \mathrm{~mm}$ level, had the lowest penetration $(\mathrm{P}<0.05)$. At a level of $10 \mathrm{~mm}$, there was no significant difference in the depth of sealer penetration between lateral condensation, continuous wave condensation, and single cone techniques $(\mathrm{P}>0.05)$. However, Thermafill $^{\circledR}$ exhibited the maximum penetration at this level $(\mathrm{P}<0.05)$.

The means ( \pm standard deviation) of GP/SR are presented in Table 2 . There were no significant differences between the different sections for continuous wave condensation and single cone techniques $(\mathrm{P}>0.05)$. However, in Group 2, where a lateral condensation technique was used, GP/SR was significantly higher in the middle and coronal thirds compared to the apical third $(\mathrm{P}<0.05)$. There were no statistical differences between the middle and coronal thirds $(\mathrm{P}>0.05)$. In the Thermafill ${ }^{\circledR}$ group (Group 4), GP/SR in the coronal third was significantly higher than that in the apical third $(\mathrm{P}<0.05)$.

When we compared the mean of the measurements of the apical, middle, and coronal thirds between the groups, mean GP/SR was highest in the Thermafill $^{\circledR}$ group, followed by continuous wave condensation, lateral condensation, and single cone technique, in that order $(\mathrm{P}<0.05)$ (Figure 1$)$. 

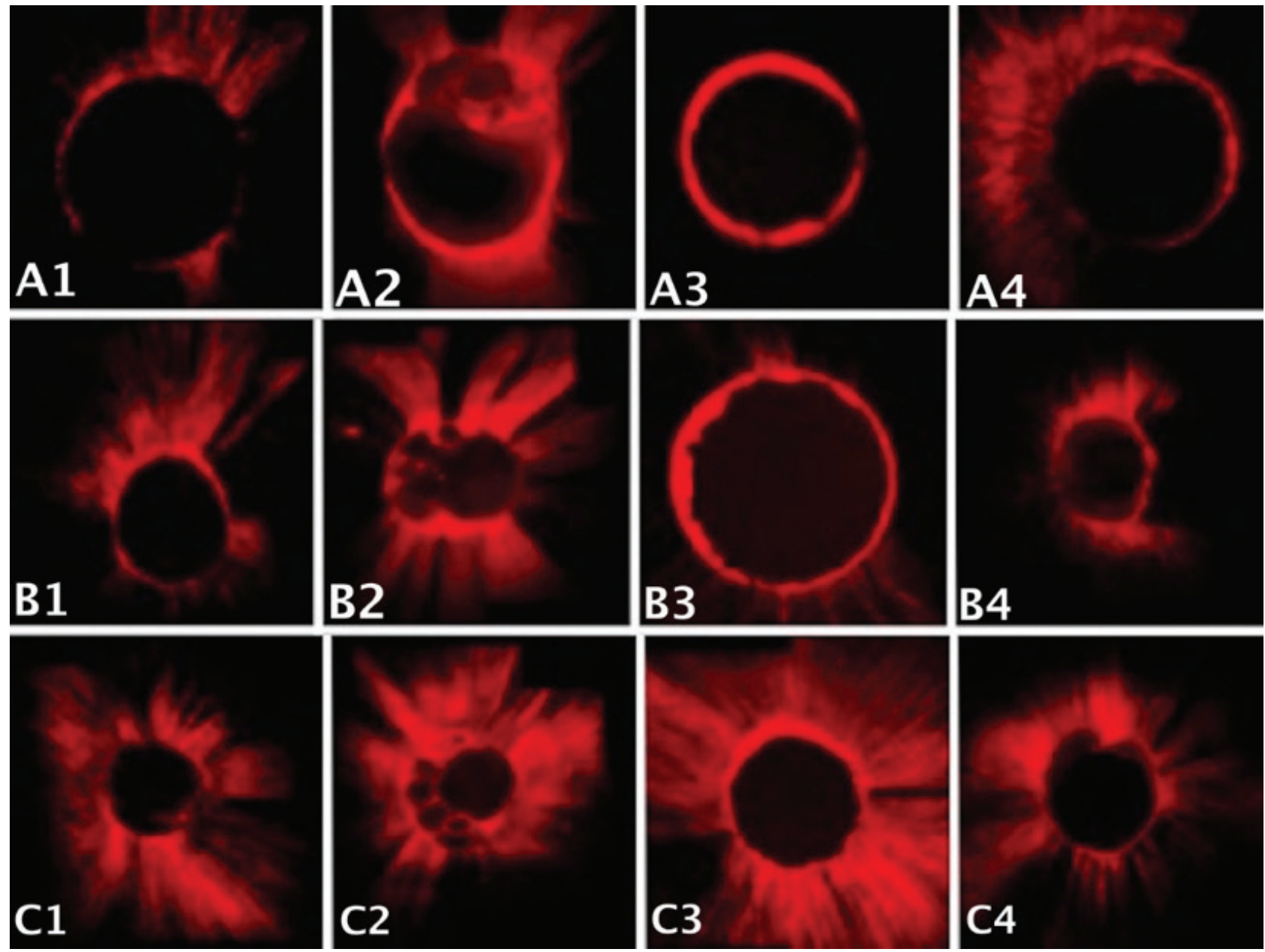

Figure 1- Confocal laser scanning microscopy images showing A. apical, B. middle, C. coronal sections in groups 1 to 4 (left to right).

\section{DISCUSSION}

In the present study, the influence of root canal filling techniques on the penetration of an endodontic sealer into dentinal tubules and the GP/sealer ratio was evaluated. It was found that sealer penetration of single-cone technique was significantly lower than that of other 3 techniques in apical and middle root thirds. Moreover, sealer thickness was significantly dependent on obturation technique.

In previous studies that aimed to evaluate dentin tubule penetration and adaptation of root canal sealers, either scanning electron microscopy (SEM) $[17,18]$ or light microscopy $[19,20]$ was used. The SEM method requires the samples to be plated with gold, which damages them. Additionally, at higher magnifications, it does not allow for a complete examination of the sample surface [21]. Another disadvantage of this method is that it only provides limited information about the root canal because it only allows a very limited evaluation of the canal wall. The difficulty with light microscopy is its inability to distinguish between the sealer and the radicular dentin.

Confocal laser scanning microscopy has recently been introduced and has some advantages over other methods. First, it allows complete examination of the sample surface at lower magnifications. Second, it does not require any additional procedures, so that 3-D images can be obtained without damaging the sample. Third, there are fewer artifacts, which 
allows direct measurement of resin-dentin interfacial gaps and teeth are not dehydrated using this method. Fourth, with this method, it is possible to evaluate the relative quantities of canal sealer and GP (GP/SR), dentin tubule penetration, and depth.

The results of this study show that in all experimental groups, the maximum depth of sealer penetration was observed in the coronal thirds, followed by the middle thirds, and was least in the apical thirds of the root canal. These results are in concordance with those of previous studies $[20,22,23]$. This may be a result of better removal of the smear layer in the coronal thirds than in the apical thirds of root canals, which may, in turn, be because of the fact that there are more dentinal tubules in the coronal area, and the diameters of the tubules in the coronal area are larger than the diameters of those in the apical area [24].

The overall depth of sealer penetration (without differentiation into coronal, middle, and apical thirds) was lowest in Group 3, i.e. the single master cone technique $(\mathrm{P}<0.05)$. A limitation of the current study was that nonuse of Lentulo, which may have affected the results of the single cone technique. However, there were no statistically significant differences between continuous wave condensation, lateral condensation and Thermafill ${ }^{\circledR}$ groups (P $>0.05)$. Weis et al. [20] and Kok et al. [25] reported similar results where they did not find any effects of root canal obturation techniques on sealer penetration into dentin tubules. However, our results showed that the single cone obturation technique was ineffective compared to other techniques.

In previous studies where root canal obturation techniques were evaluated for their properties of adaptation to dentin walls and leakage/sealing, it was shown that the single cone technique had the worst results compared to other GP canal approaches [26-28]. Similarly, our results showed that the worst results were obtained in the single cone obturation technique group. We believe that one of the reasons for this is inadequate penetration. In other techniques that we used, it was shown that GP applied a certain pressure to dentin walls. Adaptation to canal walls happens with the help of a spreader in lateral condensation, with the help of a plugger in vertical condensation, and by the use of pressure in the Thermafill ${ }^{\circledR}$ groups. This pressure helps the canal sealer penetrate into the dentin tubules. However, in the single cone technique, the tubule sealer is not pushed towards the dentin wall. This can be the underlying reason behind the insufficient tubule penetration for the single cone technique.

The single master cone technique had the lowest GP/SR among all the groups, for all the sections. Among the other three groups, Thermafill $^{\circledR}$ showed the highest GP/SR, followed by continuous wave condensation and lateral condensation, in that order $(P<0.05)$ . There are many other studies in the literature with similar results [29-32]. While laboratory studies provide precious data, the results of such studies must be extrapolated to clinical situations with caution.

In contrast to the results of our study, De Deus et al. [33] and Emmanuel et al. [34] reported no significant difference between System B and lateral condensation in their studies. We believed that this discrepancy between our results and those of previous studies might be attributable to differences in the imaging methods used.

\section{CONCLUSIONS}

We found that canal obturation techniques (Thermafill ${ }^{\circledR}$, lateral condensation, continuous wave condensation) have an insignificant effect on tubule sealer penetration into dentin canals, with the exception of the single master cone technique, which results in insufficient penetration. It was also found that obturation techniques have a significant effect on GP/SR. The Thermafill ${ }^{\circledR}$ group had the highest GP/SR, and the single cone group the lowest. Thus, we can conclude that, when compared to other GP 
techniques, the single cone technique results in the least satisfactory results for both dentin tubule penetration and GP/SR.

\section{Conflicts of interest}

The authors have no conflicts of interest relevant to this article.

\section{REFERENCES}

1. Schilder H. Filling root canals in three dimensions. Dent Clin North Am 1967 Nov:723-44.

2. Wennberg A, Orstavik $D$. Adhesion of root canal sealers to bovine dentine and gutta-percha. Int Endod J 1990 Jan;23(1):13-9. doi: 10.1111/.j.13652591.1990.tb00797.x

3. Mayo CV, Montgomery S, de Rio C. A Computerized method for evaluating root canal morphology. J Endod 1986 Jan;12(1):2-7. doi: 10.1016/s00992399(86)80274-6.

4. Ingle JI, Bakland LK. Endodontics. 5th ed. London: BC Decker Inc; 2002.

5. Lea CS, Apicella MJ, Mines P, Yancich PP, Parker MH. Comparison of the obturation density of cold lateral compaction versus warm vertical compaction using the continuous wave of condensation technique. J Endod 2005 Jan;31(1):37-9. doi: 10.1097/01.don.0000129037.75547.80.

6. Lipski, M. Root surface temperature rises during root canal obturation, in vitro, by the continuous wave of condensation technique using System B HeatSource. Oral Surg Oral Med Oral Pathol Oral Radiol Endod 2005 Apr; 99(4):505-10. doi: 10.1016/j.tripleo.2004.07.014.

7. Oguntebi BR, Shen C. Effect of different sealers on thermoplasticized Gutta-percha root canal obturations. J Endod 1992 Aug; 18(8): 363-6. doi: 10.1016/s0099-2399(06)81219-7.

8. Peters DD. Two-year in vitro solubility evaluation of four gutta-percha sealer obturation techniques. J Endod 1986 Apr; 12(4): 139-45. doi: 10.1016/ S0099-2399(86)80051-6.

9. Wu MK, Wesselink PR, Boersma, J. A 1-year follow-up study on leakage of four root canal sealers at different thicknesses. Int Endod J 1995 Jul; 28(4): 185-9. doi: 10.1111/.j.1365-2591.1995.tb00297.x.

10. Kontakiotis EG, Wu MK, Wesselink PR. Effect of sealer thickness on long-term sealing ability: a 2-year follow-up study. Int Endod J 1997 Sep;30(5):307-12. doi:10.1046/j.1365-2591.1997.00087.x.

11. DuLac KA, Nielsen CJ, Tomazic TJ, Ferrillo PJ Jr, Hatton JF. Comparison of the obturation of lateral canals by six techniques. J Endod 1999 May;25(5): 376-80. doi: 10.1016/S0099-2399(06)81175-1.

12. Leonardo MV, Goto EH, Torres CR, Borges AB, Carvalho CA, Barcellos $D C$. Assessment of the apical seal of root canals using different filling techniques. J Oral Sci 2009 Dec;51(4): 593-9. doi: 10.2334/josnusd.51.593.

13. Dalat DM, Spångberg LS. Comparison of apical leakage in root canals obturated with various gutta percha techniques using a dye vacuum tracing method. J Endod 1994 Jul;20(7):315-9. doi: 10.1016/s00992399(06)80092-0.

14. Gordon MP, Love RM, Chandler NP. An evaluation of 06 tapered guttapercha cones for filling of 06 taper prepared curved root canals. Int Endod J 2005 Feb;38(2):87-96. doi: 10.1111/j.1365-2591.2004.00903.x.
15. Romania C, Beltes P, Boutsioukis C, Dandakis C. Ex-vivo area-metric analysis of root canal obturation using gutta-percha cones of different taper. Int Endod J 2009 Jun; 42(6):491-8. doi:10.1111/j.13652591.2008.01533.x.

16. Buchanan LS The continuous wave of obturation technique: centered condensation of warm gutta-percha in 12 seconds.Dent Today 1996 Jan;15(1): 60-2, 64-7.

17. Kokkas AB, Boutsioukis A, Vassiliadis LP, Stavrianos CK. The influence of the smear layer on dentinal tubule penetration depth by three different root canal sealers: an in vitro study. J Endod 2004 Feb; 30(2):100-2. doi: 10.1097/00004770-200402000-00009

18. Mamootil K, Messer HH. Penetration of dentinal tubules by endodontic sealer cements in extracted teeth and in vivo. Int Endod J 2007 Nov; 40(11): 873-81. doi: 10.1111/j.1365-2591.2007.01307.x.

19. De Deus GA, Gurgel-Filho ED, Maniglia-Ferreira C, Coutinho-Filho T. The influence of filling technique on depth of tubule penetration by root canal sealer: a study using light microscopy and digital image processing. Aust Endod J 2004 Apr; 30(1):23-8. doi: 10.1111/j.1747-4477.2004.tb00164.x.

20. Weis MV, Parashos P, Messer HH. Effect of obturation technique on sealer cement thickness and dentinal tubule penetration. Int Endod J 2004 0ct; 37(10): 653-63. doi: 10.1111/j.j1365-2591.2004.00839.x.

21. Kara Tuncer A, Unal B. Comparison of sealer penetration using the EndoVac irrigation system and conventional needle root canal irrigation. J Endod 2014 May;40(5): 613-7. doi: 10.1016/j.joen.2013.11.017.

22. Balguerie E, Van der Sluis L, Vallaeys K, Gurgel-Georgelin M, Diemer F. Sealer penetration and adaptation in the dentinal tubules: a scanning electron microscopic study. J Endod 2011 Nov;37(11): 1576-9. doi: 10.1016/j. joen.2011.07.005

23. Balguerie E, Van der Sluis L, Vallaeys K, Gurgel-Georgelin M, Diemer F. Sealer penetration and adaptation in the dentinal tubules: a scanning electron microscopic study. J Endod 2011 Nov;37(11): 1576-9. doi: 101016/j. joen.2011.07.005.

24. Ravi SV, Nageswar R, Swapna H, Sreekant P, Ranjith M, Mahidhar S. Epiphany sealer penetration into dentinal tubules:Confocal laser scanning microscopic study. J Conserv Dent 2014 Mar;17(2):179-82. doi: 10.4103/0972-0707.128056.

25. Mjor IA, Smith MR, Ferrari M, Mannocci F. The structure of dentine in the apical region of human teeth. Int Endod J 2001 Jul; 34(5): 346-53. doi: 10.1046/j.1365-2591. 2001. 00393.x.

26. Kok D, Duarte M, Abreu da Rosa R, Wagner MH, Pereira JR, Só MV. Evaluation of epoxy resin sealer after three root canal filling techniques by confocal laser scanning microscopy. Microsc Res Tech 2012 Sep; 75(9): 1277-80. doi: 10.1002/jemt.22061.

27. Wu MK, Ozok AR, Wesselink PR. Sealer distribution in root canals obturated by three techniques. Int Endod J 2000 Jul; 33(4):340-5. doi: 10.1046/j.1365-2591.2000. 00309.x.

28. Schafer E, Nelius B, Bürklein S. A comparative evaluation of gutta-percha filled areas in curved root canals obturated with different techniques. Clin Oral Invest 2012 Feb; 16(1):225-30. doi: 10.1007/s00784-011-0509-z.

29. Robberecht L, Colard T, Claisse-Crinquette A. Qualitative evaluation of two endodontic obturation techniques: tapered single-cone method versus warm vertical condensation and injection system: an in vitro study. J Oral Sci 2012 Mar; 54(1): 99-104. doi: 10.2334/josnusd.54.99

30. Gençoğlu N. Comparison of 6 different gutta-percha techniques (part II): Thermafil, JS Quick-Fill, Soft Core, Microseal, System B, and lateral condensation. Oral Surg Oral Med Oral Pathol Oral Radiol Endod 2003 Jul;96(1): 91-5. doi: 10.1016/s1079-2104(02)91704-x. 
31. Liewehr FR, Kulild JC, Primack, PD. Improved density of gutta-percha after warm lateral condensation. J Endod 1993 0ct; 19(10): 489-91. doi: 10.1016/ S0099-2399(06)81488-3.

32. Nelson EA, Liewehr FR, West LA. Increased density of gutta-percha using a controlled heat instrument with lateral condensation. J Endod 2000 Dec;26(12): 748-50. doi: 10.1097/00004770-200012000-00021.

33. Naseri M, Kangarlou A, Khavid A, Goodini M. Evaluation of the quality of four root canal obturation techniques using micro-computed tomography. Iran Endod J 2013 Summer; 8(3): 89-93.
34. De-Deus G, Maniglia-Ferreira CM, Gurgel-Filho ED, Paciornik S, Machado AC, Coutinho-Filho T. Comparison of the percentage of gutta-percha-filled area obtained by Thermafill and System B. Aust Endod J 2007 Aug; 33(2): 55-61. doi: 10.1111/j.1747-4477.2007.00047.x.

35. Emmanuel S, Shantaram K, Sushil KC, Manoj L. An in-vitro evaluation and comparasion of apical sealing ability of three different obturation technique-lateral condensation, Obtura II, and Thermafill. J Int Oral Health $2013 \mathrm{Apr} ; 5$ (2): 35-43.

\section{Fatma Macit Ermis}

(Corresponding address)

Istanbul Medipol Üniversitesi Diş Hekimliği Fakültesi Endodonti Anabilim Dalı, Esen-

ler Hastanesi, Esenler, Istanbul/Turkey

Date submitted: 2019 Dec 04

E-mail: fatmazehramacit@gmail.com 